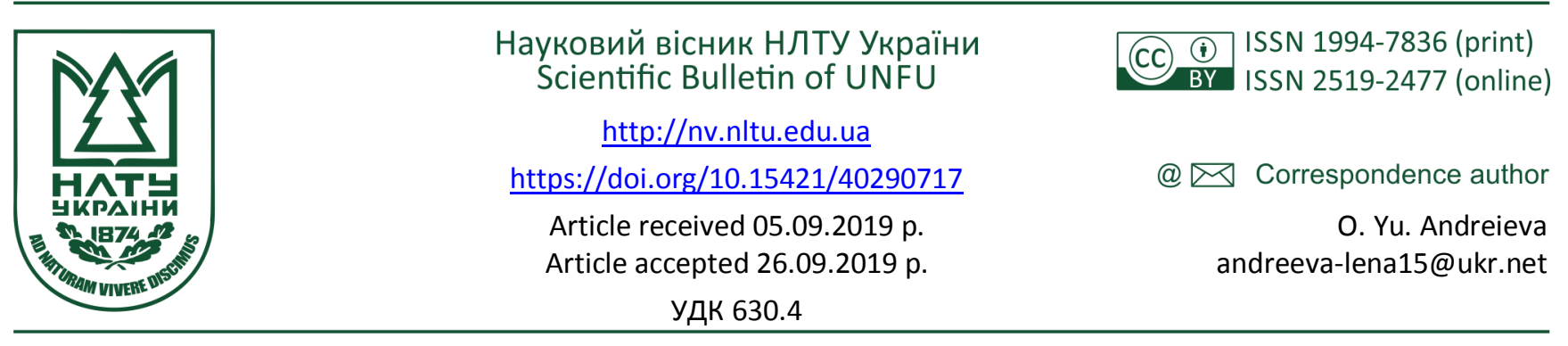

О. Ю. Андреєва ${ }^{1}$, О. Г. Болюх 2

${ }^{1}$ Житомирський національний агроекологічний університет, м. Житомир, Украӥна 2 Державне спеціалізоване лісозахисне підприємство "Вінницялісозахист", м. Вінниця, Україна

\title{
МАСОВI РОЗМНОЖЕННЯ ЗВИЧАЙНОГО СОСНОВОГО ПИЛЬЩИКА (DIPRION PINI L.) У ЛІСОВОМУ ФОНДІ ЖИТОМИРСЬКОЇ ОБЛАСТІ
}

Оцінено параметри динаміки масових розмножень звичайного соснового пильщика (Diprion pini Linnaeus 1758: Hymenoptera; Diprionidae) у лісовому фонді Житомирської області. Визначено наявність трьох спалахів (1993-1995, 2000-2002 і 2010-2012 рр.) із найбільшою площею осередків у 2000-2002 рр. Доведено, що початку масового розмноження звичайного соснового пильщика сприяли підвищення температури повітря, ранній початок вегетаційного періоду та збільшення його тривалості. Це створило умови для успішного розвитку двох поколінь і росту чисельності наприкінці вегетаційного періоду, коли пошкодження личинками хвої є найнебезпечнішим для сосни. Показано, що площа осередків масового розмноження звичайного соснового пильщика визначалася структурою лісового фонду. На прикладі лісового фонду ДП "Малинське ЛГ" проаналізовано зміни вікової структури та складу порід соснових насаджень за даними лісовпорядкувань 1997 та 2010 рр. Встановлено, що площа осередків шкідника у 2010-2012 рр., порівняно зі спалахом 2000-2002 рр., зменшилася внаслідок збільшення віку насаджень, які втратили принадність для цього виду, та зменшення площі чистих соснових насаджень, зокрема розташованих біля зрубів суцільних санітарних рубок і рубок головного користування. Доведено високу ймовірність нового зростання чисельності звичайного соснового пильщика найближчим часом. Уточнення прогнозованої площі осередків має бути проведено за даними останнього лісовпорядкування, яке візьме до уваги зміни в лісовому фонді, зокрема пов'язані з катастрофічним поширенням осередків "короїдного всихання".

Ключові слова: спалахи масового розмноження; динаміка популяцій; температура повітря; структура лісового фонду.

Вступ. Звичайний сосновий пильщик (Diprion pini Linnaeus 1758: Hymenoptera; Diprionidae) - один із небагатьох шкідників хвої сосни, який спроможний розвиватися у двох поколіннях на рік (Hentschel et al., 2018; Meshkova et al., 2019). Зазвичай у південних регіонах він має два покоління, а у північних, гірських й у холодні роки - одне (Neuvonen \& Viiri, 2017). Личинки весняного покоління живляться у квітні-травні, а літнього - у серпні-вересні. За наявності двох поколінь чисельність популяції шкідника помітно зростає за сезон. Шкідливість личинок літнього покоління $є$ також більшою, оскільки вони знищують хвою поточного року, й дерева не мають часу відновити крону (Meshkova, 2009).

Навіть у сприятливі для звичайного соснового пильщика роки осередки його масового розмноження виникають не повсюдно, а в найбільш принадних насадженнях, які визначають тип лісорослинних умов, склад порід, вік і повнота насаджень (Andreieva, 2014; Nevalainen et al., 2015; Blomqvist et al., 2016; Meshkova \& Kolienkina, 2016; Kosunen et al., 2017; Ziesche, 2017). Побудовано балові оцінки принадності насаджень для цього шкідника, які дають змогу прогнозувати очікувані площі осередків за матеріалами лісовпорядкування
(Meshkova, 2009), а з використанням сучасних ГIC-технологій врахувати також розташування ділянок у лісі, зокрема сусідство зі зрубами (Meshkova \& Borysenko, 2017).

Масові розмноження звичайного соснового пильщика зазвичай тривають не більше чотирьох років із високою чисельністю упродовж двох років (Nadzor, 1965). Згасання спалахів відбувається під впливом комах-ентомофагів або хвороб (Dalasoglu et al., 2016; Simsek \& Kondur, 2017).

Масові розмноження звичайного соснового пильщика у Житомирській обл. із 60-х до середини 90-х років $\mathrm{XX}$ ст. невідомі. Це пояснювали сприятливими для лісу природними умовами Полісся, різноманіттям вікового й породного складу та стійкістю до шкідників (Meshkova, 2009; Andreieva, 2014). Від середини 90-х років донині відбулося три спалахи звичайного соснового пильщика, причому другий був найсильнішим (Anonimous, 2018). Згідно з робочою гіпотезою, виникненню спалахів цього шкідника сприяло потепління, за якого створилися умови для розвитку двох поколінь шкідника. 3 іншого боку, площа осередків визначалася площею принадних ділянок, яка не була постійною за ці роки, оскільки змінювалися вік, склад, повнота тощо.

\section{Інформація про авторів:}

Андреєва Олена Юріївна, канд. с.-г. наук, доцент, кафедра експлуатації лісових ресурсів. Email: andreeva-lena15@ukr.net; https://orcid.org/0000-0003-0851-800X

Болюх Олександр Григорович, головний лісопатолог. Email: agboluh@ukr.net

Цитування за ДСТУ: Андреєва О. Ю., Болюх О. Г. Масові розмноження звичайного соснового пильщика (Diprion Pini L.) у лісовому фонді Житомирської області. Науковий вісник НлтУ України. 2019, т. 29, № 7. С. 84-89.

Citation APA: Andreieva, O. Yu., Boliujh, O. G. (2019). The Outbreaks of Common Pine Sawfly (Diprion Pini L.) In the Forest Fund of Zhytomyr Region. Scientific Bulletin of UNFU, 29(7), 84-89. https://doi.org/10.15421/40290717 
Мета досліджень - оцінити чинники впливу на розвиток масових розмножень звичайного соснового пильщика у лісовому фонді Житомирської області.

Матеріал і методи. В аналізі використано матеріали статистичної звітності Житомирського обласного управління лісового господарства, лісогосподарських підприємств Житомирської обл., Вінницького лісозахисного підприємства (Anonimous, 2018) і результати власних досліджень. Дати переходу температури через 5, 10 i $15^{\circ} \mathrm{C}$ за даними метеостанції Житомир за 19452018 pp. розраховували за методичним підходом В. Л. Мєшкової (Meshkova, 2009), користуючись пакетом програм MS Excel.

Принадність насаджень для формування осередків звичайного соснового пильщика оцінювали за підходом В. Л. Мєшкової (Meshkova, 2009) за базою даних лісового фонду ДП "Укрдержліспроект" станом на 1997 i 2010 pр. Статистичний аналіз даних здійснювали за допомогою пакету програм MS Excel (Atramentova \& Utevskaya, 2008).

Результати дослідження. Перші за багато років спалахи звичайного та рудого (Neodiprion sertifer Geoffroy, 1785) соснових пильщиків у лісах Житомирської обл. зареєстровано у 1993-1995 рр. Наступний період зростання чисельності популяцій цих комах розпочався у 2000 p., a у 2002 р. площа осередків перевищила 40 тис. га. У ці роки у лісовому фонді державних підприємств (ДП) "Овруцьке лісове господарство (ЛГ)" і "Смільчинське ЛГ" переважали осередки масового розмноження рудого соснового пильщика, а в решті лісгоспів площі осередків обох видів обліковували разом. У 2010-2012 pр. реєстрували масове розмноження тільки звичайного соснового пильщика, який є більш небезпечним, аніж рудий сосновий пильщик, із декількох причин. Так, рудий сосновий пильщик завжди розвивається в одному покоління на рік, личинки живляться хвоєю минулого року з кінця квітня до кінця травня початку червня, тобто пагони та хвоя поточного року встигають завершити розвиток, і пошкоджені дерева дуже зрідка гинуть. На відміну від цього виду, звичайний сосновий пильщик спроможний розвиватися у двох поколіннях на рік, причому найнебезпечнішим є друге, личинки якого живляться хвоєю поточного року у серпні-вересні. Тому дерева не встигають відновити асиміляційний апарат у разі сильного пошкодження хвої цим шкідником, що позначається як на їхньому прирості, так і на життєздатності.

Основною причиною поширення осередків масового розмноження звичайного соснового пильщика у Житомирській обл. на початку третього тисячоліття $\epsilon$ зміна клімату, яка виявилася у підвищенні температури повітря (рис. 1).



Рис. 1. Середня місячна температура повітря за періоди 19451994 та 1995-2019 рр. за даними метеостанції Житомир

Наслідком таких змін стали більш ранні дати початку вегетаційного періоду та збільшення його загальної тривалості (табл. 1).

Так, стійкий перехід температури повітря через $5{ }^{\circ} \mathrm{C}$ упродовж десятиліть реєстрували у першій декаді квітня, а у 1995-2019 pp. - у третій декаді березня. Закінчення періоду з температурою понад $5^{\circ} \mathrm{C}$ стало пізнішим, а тривалість зросла від 201 до 222 днів. Стійкий перехід температури повітря через $10{ }^{\circ} \mathrm{C}$ реєстрували у 1945-2004 pp. у третій декаді квітня, а у 2005-2019 рр. у середньому 15 квітня. Закінчення періоду з температурою понад $10^{\circ} \mathrm{C}$ стало пізнішим на 15 днів, а тривалість зросла від 159 до 184 днів. Дата стійкого переходу температури повітря через $15^{\circ} \mathrm{C}$ посунулася на більш ранню дату майже на два тижні, а тривалість періоду зросла до 132 днів (див. табл. 1).

Табл. 1. Межі та тривалість періодів із температурою понад 5,10 i $15{ }^{\circ} \mathrm{C} \mathrm{у} \mathrm{різні} \mathrm{десятиліття} \mathrm{за} \mathrm{даними}$ метеостанції Житомир

\begin{tabular}{|c|c|c|c|c|c|c|}
\hline \multirow{2}{*}{ Період років } & \multicolumn{2}{|c|}{ Температура $>5^{\circ} \mathrm{C}$} & \multicolumn{2}{|c|}{ Температура $>10^{\circ} \mathrm{C}$} & \multicolumn{2}{|c|}{ Температура $>15^{\circ} \mathrm{C}$} \\
\hline & межі, дати & тривалість, дні & межі, дати & тривалість, дні & межі, дати & тривалість, дні \\
\hline $1945-1954$ & 5.04. - 22.10 & 201 & $25.04 .-30.09$ & 159 & $23.05 .-6.09$ & 107 \\
\hline $1955-1964$ & 9.04. - 30.10. & 205 & 30.04. - 1.10. & 155 & $26.05 .-1.09$. & 99 \\
\hline $1965-1974$ & 5.04. - 29.10 & 208 & $28.04 .-2.10$ & 158 & $29.05 .-1.09$. & 96 \\
\hline $1975-1984$ & 5.04. - 28.10 & 207 & $28.04 .-3.10$ & 159 & $28.05 .-3.09$. & 99 \\
\hline 1985-1994 & $3.04 .-26.10$ & 207 & $26.04 .-1.10$. & 159 & $28.05 .-3.09$. & 99 \\
\hline $1995-2004$ & $31.03 .-30.10$. & 214 & $23.04 .-1.10$. & 162 & $21.05 .-3.09$ & 106 \\
\hline $2005-2019$ & $26.03 .-2.11$ & 222 & 15.04. - 15.10. & 184 & $12.05 .-20.09$. & 132 \\
\hline
\end{tabular}

Такі зміни температурного режиму дають змогу успішно завершити розвиток додаткових поколінь полівольтинним видам комах, зокрема звичайному сосновому пильщику та короїдам, які заселили ослаблені ним дерева, - верхівковому Ips acuminatus (Gyllenhal, 1827) та шестизубчастому Ips sexdentatus (Boerner, 1767) (Coleoptera: Curculionidae: Scolytinae).

Другою важливою причиною збільшення площі осередків масового розмноження звичайного соснового пильщика останніх десятиліть $є$ зміни у структурі лісового фонду та збільшення кількості виділів, принадних для розвитку цієї комахи. Як відомо (Meshkova, 2009), принадність насаджень для розвитку комах визна- чається сукупністю характеристик, таких як тип лісорослинних умов, склад, вік, повнота насаджень і фактом межування ділянки зі свіжим зрубом, згарищем тощо. Чим більше виділів мають високу принадність для певного шкідника, тим більшою може бути площа осередку за умов, сприятливих для масового розмноження цієї комахи.

Так, у період спалаху на початку третього тисячоліття найбільшу площу осередків звичайного соснового пильщика зареєстровано у лісовому фонді ДП "Малинське ЛГ", яка становила в середньому 9580 га, а максимальна (у 2002-2003 рр.) сягала 15768 га (табл. 2). 
Друге місце посідали осередки звичайного соснового пильщика в ДП "Радомишльське ЛГ", максимальна площа яких у 2002-2003 рр. сягала 10360 га. Площа осередків цього шкідника у ДП "Народицьке ЛГ" мало змінювалася у 2002-2009 рр. Це свідчить про те, що осередки тримали на обліку навіть після їхнього згасання. У решті лісгоспів (Овруцькому та Коростишівському) площа осередків звичайного соснового пильщика становила в середньому близько 500 га, та їх реєстрували тільки упродовж двох-трьох років (див. табл. 2).

Табл. 2. Площа осередків звичайного соснового пилыщика у лісовому фонді державних лісогосподарських підприсмств Житомирської області станом на початок 2000$2019 \mathrm{pp}$.

\begin{tabular}{|c|c|c|c|c|c|c|}
\hline \multirow{3}{*}{$\begin{array}{l}\text { Державне } \\
\text { підпр-во }\end{array}$} & \multirow{2}{*}{\multicolumn{6}{|c|}{ Площа, га }} \\
\hline & & & & & & \\
\hline & $\begin{array}{c}\text { серед- } \\
\text { ня }\end{array}$ & $\begin{array}{l}\text { макси- } \\
\text { мальна }\end{array}$ & $\begin{array}{c}\text { серед- } \\
\text { ня }\end{array}$ & $\begin{array}{l}\text { макси- } \\
\text { мальна }\end{array}$ & $\begin{array}{c}\text { серед- } \\
\text { ня }\end{array}$ & $\begin{array}{l}\text { макси- } \\
\text { мальна }\end{array}$ \\
\hline Малинське & 9580 & 15768 & 6512 & 9386 & 5949 & 15768 \\
\hline Народицьке & 4866 & 5470 & 235 & 402 & 3117 & 5470 \\
\hline $\begin{array}{l}\text { Радомиш- } \\
\text { льське }\end{array}$ & 5737 & 10360 & 1365 & 1432 & 2247 & 10360 \\
\hline Овруцьке & 505 & 608 & - & - & 505 & 608 \\
\hline $\begin{array}{l}\text { Коростишів- } \\
\text { ське } \\
\end{array}$ & 500 & 500 & - & - & 500 & 500 \\
\hline
\end{tabular}

Наступний ріст чисельності звичайного соснового пильщика та площі його осередків зареєстровано після посушливого 2009 р. (256 мм опадів за вегетаційний період, тобто 81 \% від норми) у лісовому фонді трьох державних лісогосподарських підприємств Житомирської обл. - "Малинське ЛГ", "Народицьке ЛГ" та "Радомишльське ЛГ" (див. табл. 2).

Зіставлення результатів обліку коконів звичайного соснового пильщика у лісовому фонді двох лісогосподарських підприємств у 2000-2014 рр. свідчить, що спалахи масового розмноження цього шкідника розвивалися синхронно (рис. 2).

Вважають (Nadzor, 1965), що пошкодження крон сосни на $100 \%$ відбувається за наявності 13 коконів самок звичайного соснового пильщика на $1 \mathrm{~m}^{2}$, а рівень загрози, за якого потрібно призначати заходи зі захисту соснових насаджень, сягає 30 \%. Тобто за наявності чо-

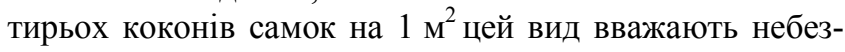
печним. За нашими даними, самки становили в різні роки 0,5-0,6 від загальної чисельності коконів звичайного соснового пильщика.

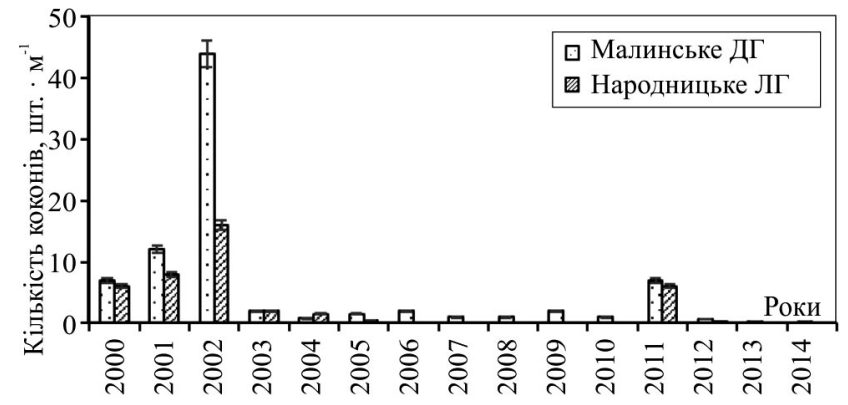

Рис. 2. Динаміка щільності коконів звичайного соснового пильщика у насадженнях ДП "Малинське ЛГ" та "Народицьке ЛГ" у 2000-2015 pp.

Тобто небезпека значного пошкодження лісового фонду досліджуваних підприємств личинками звичайного соснового пильщика існувала у 2000-2002 pp. та у 2011 р. (див. рис. 2). Саме в ці роки й було застосовано вірусні препарати та хімічні інсектициди для захисту лісу.
За результатами обстеження насаджень виявлено, що осередки масового розмноження звичайного соснового пильщика почали згасати як у насадженнях, де застосовували вірусний препарат чи хімічні інсектициди у 2003 і 2013 рр. відповідно, так і за відсутності цього заходу. Водночас за високої чисельності звичайного соснового пильщика у рік кульмінації спалаху масового розмноження та за відсутності захисних заходів крони дерев сосни були помітно пошкоджені у другій половині літа (під час розвитку літнього покоління шкідника). Найдужче потерпали захисні смуги лісів уздовж автомобільних доріг і залізниць, а також насадження, які межували зі зрубами рубок головного користування та суцільних санітарних рубок.

Тому на тлі згасання осередків звичайного соснового пильщика збільшувалася площа осередків стовбурових шкідників і площа насаджень, на яких проведено вибіркові санітарні рубки (від 15,2 тис. га у 2001 р. до 18,6 тис. га у 2004 р. та 19,2 тис. га у 2005 р.). За період 2009-2018 рр. суцільні санітарні рубки в соснових лісах Житомирської обл. проведені на площі 19,5 тис. га, а вибіркові санітарні рубки- на площі 198 тис. га (рис. 3).

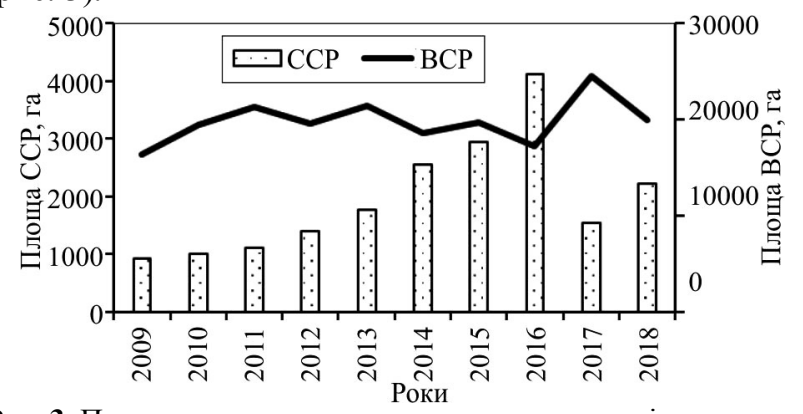

Рис. 3. Площа соснових насаджень, охоплених суцільними (ССР) та вибірковими (ВСР) санітарними рубками у лісовому фонді Житомирського ОУЛМГ у 2009-2018 рр. (побудовано за Anonimous, 2018)

Варто зауважити, що до площі вибіркових санітарних рубок зараховують усю площу виділу, причому у кожному виділі цей захід зазвичай повторюють не менше трьох разів, аж поки повнота насадження відповідатиме умовам, необхідним для призначення суцільної санітарної рубки. Тому фактична площа, охоплена вибірковими санітарними рубками, є значно меншою.

Згідно $з$ даними табл. 2, у лісовому фонді всіх проаналізованих підприємств площа осередків звичайного соснового пильщика у 2010-2015 pр. була значно меншою (середня річна - в 1,5; 20,7 і 4,2 раза, а максимальна - у 1,7; 13,6 і 7,2 раза у ДП "Малинське ЛГ", "Народицьке ЛГ" та "Радомишльське ЛГ" відповідно), ніж у 2000-2005 pр. Різниці у середній площі осередків за період двох спалахів становили 3068, 4631 і 4372 га, а у максимальній - 6382, 5068 і 8928 га у ДП "Малинське ЛГ", "Народицьке ЛГ" та "Радомишльське ЛГ" відповідно.

Отримані дані можна пояснити тим, що внаслідок ослаблення насаджень, розвитку осередків усихання 3 участю короїдів і проведення рубок як головного користування, так і санітарних рубок зменшилася кількість виділів, принадних для формування осередків масового розмноження соснових пильщиків, і відповідно, - площа таких осередків.

Так, аналіз матеріалів лісовпорядкування ДП "Малинське ЛГ" станом на 1997 і 2010 рр. свідчить, що 
стиглі й перестиглі соснові насадження становили в ці періоди 20,5 і 24,1 \% від усієї площі соснових лісів (рис. 4). Ці насадження не $є$ принадними для формування осередків звичайного соснового пильщика, але принадні для формування осередків короїдів.

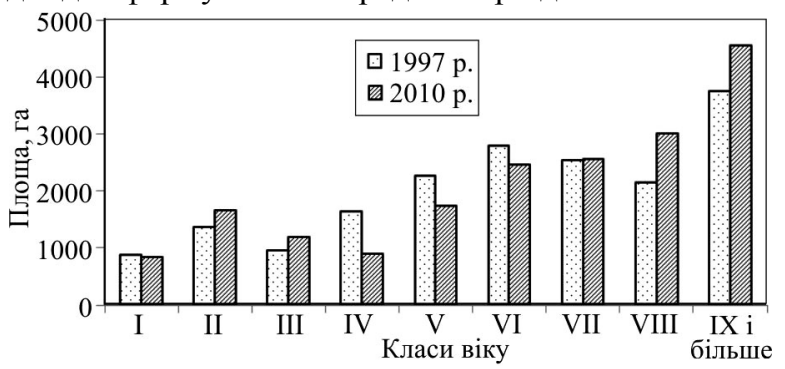

Рис. 4. Розподіл за класами віку площі соснових насаджень у лісовому фонді ДП "Малинське ЛГ" станом на 1997 та 2010 рр.

Так, площа насаджень VIII класу віку збільшилася за аналізований період від 2137,1 до 3001,1 га (на 864 га), площа насаджень IX і більших класів віку - від 3755,2 до 4560 га (на 804,8 га), тобто разом площа насаджень, не придатних для формування осередків цього шкідника у зв'язку зі збільшенням віку, зросла на 1668,8 га.

Насадження, які за віком є найбільш принадними для формування осередків звичайного соснового пильщика (V клас віку - бал 5), на початку тисячоліття становили 2255,2 га, а станом на 2010 р. - 1733 га. Насадження 3 високою принадністю для формування осередків звичайного соснового пильщика (IV клас вікубал 4), на початку тисячоліття становили 1638,7 га, а станом на 2010 р. - 886,8 га. Тобто тільки 3 урахуванням віку насаджень площа ділянок із дуже високою та високою принадністю для формування осередків звичайного соснового пильщика, зменшилася ще на 1274,1 га $(3893,9-2619,8=1274,1$ га).

За даними на 1997 р., площа чистих соснових насаджень, найбільш принадних для формування осередків соснових пильщиків, становила 9299,7га, а станом на 2010 p. - 7063,7 га, тобто на 2236 га меншою.

Разом зменшення площі насаджень, що принадні для формування у лісовому фонді ДП "Малинське ЛГ" осередків звичайного соснового пильщика, становить 5178,9 га (1668,8 га - за рахунок збільшення віку насаджень, які втратили принадність для цього шкідника, 1274,1 га - за рахунок меншої площі насаджень IV-V класів віку дуже високої та високої принадності та 2236 га - за рахунок зменшення площі чистих соснових насаджень).

Зважаючи на те, що після лісовпорядкування 2010 р. розпочалося й триває всихання соснових лісів із участю короїдів, які заселяють насамперед чисті соснові насадження (Andreieva, 2016. 2017), а також зростання площі санітарних рубок в осередках короїдного всихання та збільшення кількості виділів, які межують зі зрубами, можна пояснити й решту площі, на яку зменшилися осередки звичайного соснового пильщика під час останнього спалаху.

Обговорення результатів дослідження. Масові розмноження звичайного соснового пильщика у Житомирській обл. після тривалої перерви стали реєструвати в середині 90-х років. Наступні максимуми чисельності шкідника зафіксовано у 2000-2002 та 2010-2012 pp., причому найбільшу площу осередків виявлено у 2002 р.
Основним чинником, що сприяв росту чисельності звичайного соснового пильщика у регіоні, $є$ значний ріст температури повітря та збільшення тривалості вегетаційного періоду. Це створило умови для успішного розвитку двох поколінь і значного збільшення чисельності популяцій наприкінці вегетаційного періоду, коли пошкодження личинками хвої поточного року є найнебезпечнішим для дерев сосни. Це узгоджується 3 даними стосовно залежності динаміки популяцій комаххвоєгризів від погодних умов у різних регіонах (Meshkova et al., 2017; Möller et al., 2017; Haynes et al., 2014, 2018; Chorbadjian et al., 2019).

Значне збільшення площі осередків масового розмноження звичайного соснового пильщика під час спалаху 2000 р. пов'язане зі зростанням площі насаджень, принадних для формування осередків цього шкідника, а саме чистих соснових культур віком 30-60 років, зокрема розташованих біля зрубів суцільних санітарних рубок і рубок головного користування.

У наступні роки вікова структура та склад насаджень змінилися, що може бути основною причиною зменшення площі осередків звичайного соснового пильщика у 2011 р. порівняно з 2000 р. (Andreieva \& Martynchuk, 2017). Так, зменшилася площа чистих cocнових насаджень, в яких після посухи 2009 р. поширилися процеси всихання з участю короїдів. Частина насаджень втратила принадність для звичайного соснового пильщика у зв'язку із збільшенням віку, а частина була вилучена суцільними санітарними рубками та рубками головного користування. 3 іншого боку, збільшення кількості (та периметра) виділів, що межують із ділянками зазначених рубок, є сприятливим для ослаблення соснових насаджень, які можуть або пошкодити соснові пильщики, або заселити короїди (Andreieva, 2017; Meshkova \& Borysenko, 2017).

Результати аналізу погодних умов останніх років і даних стосовно циклічності спалахів звичайного соснового пильщика в інших регіонах свідчать про високу ймовірність нового зростання чисельності цього виду найближчим часом. Водночас точний прогноз поширення осередків можливо побудувати тільки за даними останнього базового лісовпорядкування з урахуванням усіх змін у лісовому фонді останніх років, зокрема пов'язаних 3 катастрофічним поширенням осередків "короїдного всихання".

\section{Висновки:}

1. Після 30-річної перерви спалахи звичайного (Diprion pini Linnaeus 1758) та рудого (Neodiprion sertifer Geoffroy, 1785) соснових пильщиків (Hymenoptera: Symphyta, Diprionidae) у лісах Житомирської обл. зареєстровано у 1993-1995, 2000-2002 і 2010-2012 pp.

2. Основним чинником, сприятливим для масового розмноження звичайного соснового пильщика у Житомирській обл. на початку третього тисячоліття, є підвищення температури повітря, більш ранні дати початку вегетаційного періоду та збільшення його загальної тривалості.

3. Основною причиною збільшення площі осередків масового розмноження звичайного соснового пильщика останніх десятиліть $€$ зміни у структурі лісового фонду та збільшення кількості виділів, принадних для розвитку цієї комахи (чистих соснових насаджень віком 3060 років), що межують зі зрубами.

4. Найбільшу площу осередків звичайного соснового пильщика у 2002 р. зареєстровано у лісовому фонді 
ДП "Малинське ЛГ" (15768 га.) та у ДП "Радомишльське ЛГ" (10360 га).

5. На тлі згасання осередків звичайного соснового пильщика та підвищення температури повітря збільшувалася площа осередків стовбурових шкідників і площа насаджень, на яких проведено вибіркові санітарні рубки.

6. Площа осередків звичайного соснового пильщика у 2010-2012 рр. зменшилася, порівняно зі спалахом 20002002 pp., у середньому на 3068, 4631 і 4372 га у ДП "Малинське ЛГ", "Народицьке ЛГ" та "Радомишльське ЛГ" відповідно. Це відбулося внаслідок збільшення віку насаджень, які втратили принадність для цього шкідника, та зменшення площі чистих соснових насаджень.

Andreieva, O. Y., \& Martynchuk, I. V. (2017). Dynamics of threat of pine sawflies foci spread with change of relative stocking density. The Bulletin of Kharkiv National Agrarian University. Series "Phytopathology and Entomology", 1-2, 11-17. [In Ukrainian].

Andreieva, O. Y. (2014). The prevalence of pine sawfly in Central Polissya forest stands. Herald of ZHNAEU, 1(41), 3, 140-145. [In Ukrainian].

Andreieva, O. Y. (2016). Stem pests in the foci of pine stands decline in the State Enterprise "Zhytomyr Forest Economy" of Zhytomyr region. The Bulletin of Kharkiv National Agrarian University. Series "Phytopathology and Entomology", 1-2, 3-9. [In Ukrainian].

Andreieva, O. Y. (2017). Health condition and growth of pine stands in the foci of their drying at the State Enterprise "Zhytomyr Forest "Zhytomyrs'kyy natsional'nyy ahroekolohichnyy universytet", 3-7. [In Ukrainian].

Anonimous. (2018). Report materials about the spread of diseases and pests in the forest stands of Zhyromyr Regional Forest and Hunting Administration in 2017 and prognosis for 2018. State Specialized Forest Protective Enterprise "Vinnytsyalisozahyst", 70 p. [In Ukrainian].

Atramentova, L. A., \& Utevskaya, O. M. (2008). Statisticheskiye metody v biologii. Gorlovka: Statistical methods in biology, $148 \mathrm{p}$. [In Russian].

Blomqvist, M., Lyytikäinen-Saarenmaa, P., Kantola, T., Kosunen, M., Talvitie, M., \& Holopainen, M. (2016). Impacts of natural enemies and stand characteristics on cocoon mortality of the pine sawfly Diprion pini in a Fennoscandian boreal forest. Silva Fennica., 50 (5), article id 1615. https://doi.org/10.14214/sf.1615

Chorbadjian, R. A., Phelan, P. L., \& Herms, D. A. (2019). Tight insect-host phenological synchrony constrains the life- history strategy of European pine sawfly.

Dadasoglu, F., Tozlu, G., Kotan, R., Gokturk, T., \& Karagoz, K. (2016). Biological control of pine sawfly (Diprion pini L.) and mogical Letters, 21(2), 11273.

Haynes, K. J., Tardif, J. C., \& Parry, D. (2018). Drought and surface - level solar radiation predict the severity of outbreaks of a wi-

\section{Перелік використаних джерел} Economy". Naukovi chytannya- 2017. Zhytomyr: Vyd-vo lecular characterisation of effective strains. Romanian Biotechnolo-

despread defoliating insect. Ecosphere, https://doi.org/10.1002/ecs2.2387

Haynes, K., Allstadt, A., \& Klimetzek, D. (2014). Forest defoliator outbreaks under climate change: effects on the frequency and severity of outbreaks of five pine insect pests. Global Change Biology, 20(6): 2004-2018. https://doi.org/10.1111/gcb.12506

Hentschel, R., Möller, K., Wenning, A., Degenhardt, A., \& Schröder, J. (2018). Importance of ecological variables in explaining population dynamics of three important pine pest insects. Frontiers in Plant Science, 9, 1667.

Illinski, A. I., \& Tropin, I. V. (Eds.) (1965). Survey, assessment and prediction of outbreaks of foliage browsing insects. Moskva, Lesnaja Promyshlennost, 525. [In Russian].

Kosunen, M., Kantola, T., Starr, M., Blomqvist, M., Talvitie, M., \& Lyytikäinen-Saarenmaa, P. (2017). Influence of soil and topography on defoliation intensity during an extended outbreak of the common pine sawfly (Diprion pini L.). IForest. 10: 164-171. https://doi.org/10.3832/ifor2069-009

Meshkova, V. L. (2009). Seasonal development of the foliage browsing insects. Novoe slovo, Kharkov, 396 p. [In Russian].

Meshkova, V. L., \& Borysenko, O. I. (2017). GIS-based prediction of the foliage browsing insects' outbreaks in the pine stands of the SE "Kreminske FHE". Proceedings of the Forestry Academy of Sciences of Ukraine, 15, 12-18. http://fasu.nltu.edu.ua. https://doi.org/411714

Meshkova, V. L., \& Kolienkina, M. S. (2016). Outbreaks of pine sawflies in the forest stands of Luhansk region. Planeta-Print, Kharkiv. 180 p. [In Ukrainian].

Meshkova, V. L., Nazarenko, S. V., \& Kasych, T. G. (2017). Dynamics of European pine sawfly foci area in the stands of Low Dnieper region in 2010-2017. Forestry \& Forest Melioration, 130, 215-222.

Meshkova, V., Nazarenko, S., \& Kolienkina, M. (2019). Diprion pi$n i$ L. (Hymenoptera, Symphyta, Diprionidae) population dynamics in the Low Dnieper region. Folia Forestalia Polonica, Series AForestry, 61(1), 22-29. https://doi.org/10.2478/ffp-2019-0002

Möller, K., Hentschel, R., Wenning, A., \& Schröder, J. (2017). Improved Outbreak Prediction for Common Pine Sawfly (Diprion pi$n i \mathrm{~L}$.) by Analyzing Floating 'Climatic Windows' as Keys for Changes in Voltinism. Forests, 8(9), 319; https://doi.org/10.3390/ f8090319.

Neuvonen, S., \& Viiri, H. (2017). Changing climate and outbreaks of forest pest insects in a cold northern country, Finland. In The Interconnected Arctic - UArctic Congress 2016 (pp. 49-59). Springer, Cham.

Nevalainen, S., Sirkiä, S., Peltoniemi, M., \& Neuvonen, S. (2015). Vulnerability to pine sawfly damage decreases with site fertility but the opposite is true with Scleroderris canker damage; results from Finnish ICP Forests and NFI data. Annals of forest science, 72(7), 909-917. https://doi.org/10.1007/s13595-014-0435-8

Simsek, Z., \& Kondur, Y. (2017). Determination of the natural enemies of Diprion pini L. (Hymenoptera: Diprionidae) in Cankiri, Turkey. Fresenius Environmental Bulletin, 26(11), 6749-6759.

Ziesche, T. M. (2017). Tree growth indicates resource quality for foliage-feeding insects: Pattern and structure of herbivore diversity in response to productivity. Ecological indicators, 83, 249-259. https://doi.org/10.1016/j.ecolind.2017.07.053

O. Yu. Andreieva1, 0. G. Boliujh ${ }^{2}$

${ }^{I}$ Zhytomyr National Agroecological University, Zhytomyr, Ukraine ${ }^{2}$ State Specialized Forest Protective Enterprise "Vinnytsyalisozahyst", Vinnytsya, Ukraine

\section{THE OUTBREAKS OF COMMON PINE SAWFLY (DIPRION PINI L.) IN THE FOREST FUND OF} ZHYTOMYR REGION

Outbreaks of common pine sawfly (Diprion pini Linnaeus 1758: Hymenoptera; Diprionidae) were not registered in Zhytomyr Region since 60's to mid-90's of the last century and became rather often for next 20 years. It was connected with high favorability of natural conditions of Polissya for the forest with high age and species diversity and resistance to pests. The aim of the research was the assessment of factors affecting the development of outbreaks of common pine sawfly in the forest fund of Zhytomyr Region. We used the statistical data of Zhytomyr Regional Administration of Forest and Hunting Management as well as of Vinnytsya Forest Protective Enterprise and the results of own researches in analysis. Three outbreaks of common pine sawfly (in1993-1995, 20002002 and 2010-2012) developed in the region with maximal foci area in 2000-2002. The highest foci area was registered in 2002 in 
the forest fund of Malynsky and Radomyshlsky Forest Enterprises (15768 and 10360 hectares respectively). It was shown, that an increase of air temperature, early beginning of vegetation period and increase of its duration promote the beginning of outbreak, successful development of two generations of common pine sawfly and its population growth at the end of vegetation, when needle damage is the most dangerous for pine health. The changes in forest fund structure and increase of forest subcompartments with high attractiveness for this pest, particularly pure Scots pine (Pinus sylvestris L.) stands of 30-60 years old, which border with clear-cuts were the main causes of the growth of common pine sawfly foci area. The increase of stem pests' foci after collapse of common pine sawfly outbreak together with further warming brought to the growth of selective sanitary felling area and the number of forest subcompartments with high attractiveness to pests. However, the area of common pine sawfly foci in 2010-2012 was less than in 2000-2002 on average on 3068, 4631 i 4372 hectares in Malynsky and Radomyshlsky Forest Enterprises respectively. This was due to the increase in the age of forest stands that lost their attractiveness for this pest, and by the decrease of pure pine stands area. The high probability of a new outbreak of common pine sawfly exists in the near future. In further research, predicted area of common pine sawfly foci must be evaluated after current forest inventory, which will consider all changes in the forest fund, particularly associated with the catastrophic spread of bark beetle caused drying.

Keywords: outbreak; population dynamics; air temperature; forest fund structure. 